City University of New York (CUNY)

CUNY Academic Works

2012

\title{
A SWOT model of the challenges and benefits of volunteer involvement in US non-profit organisations during times of fiscal stress
}

Helisse Levine

Long Island University

Maria J. D’Agostino

CUNY John Jay College

\section{How does access to this work benefit you? Let us know!}

More information about this work at: https://academicworks.cuny.edu/jj_pubs/352

Discover additional works at: https://academicworks.cuny.edu

This work is made publicly available by the City University of New York (CUNY).

Contact: AcademicWorks@cuny.edu 


\title{
A SWOT model of the challenges and benefits of volunteer involvement in US non-profit organisations during times of fiscal stress
}

\author{
Helisse Levine* \\ Department of Business, Public Administration \\ and Information Sciences, \\ Long Island University, \\ One University Plaza, Brooklyn, NY, 11201, USA \\ Fax: 718-488-1422 \\ E-mail: helisse.levine@liu.edu \\ *Corresponding author
}

\author{
Maria J. D’Agostino \\ John Jay College of Criminal Justice/CUNY, \\ 445 West 59th Street, New York, New York, 10019, USA \\ Fax: 212-237-8068 \\ E-mail: mdagostino@jjay.cuny.edu
}

\begin{abstract}
As a result of the current fiscal crisis, the US Federal Government is calling on non-profit organisations and communities across the country to contribute their service through volunteering. This study uses qualitative data retrieved from a purposive sample of New York City non-profit administrators to determine the challenges and benefits of volunteer involvement in US non-profit organisations during the economic downturn that began in 2008 . Findings conclude that although US Federal Government initiatives, including $\$ 50$ million of the American Recovery and Reinvestment Act allocated to the strengthening communities fund provided non-profits the opportunity to draw on an influx of a highly skilled pool of volunteers, many non-profits remain underfunded, understaffed and unequipped to make the most of those who are looking to serve.
\end{abstract}

Keywords: non-profits; volunteerism; fiscal stress; qualitative method; non-profit management; SWOT analysis.

Reference to this paper should be made as follows: Levine, $H$. and D'Agostino, M. (2012) 'A SWOT model of the challenges and benefits of volunteer involvement in US non-profit organisations during times of fiscal stress', Int. J. Society Systems Science, Vol. 4, No. 1, pp.76-91.

Biographical notes: Helisse Levine is an Assistant Professor of Public Administration for the MPA programme at Long Island University, Brooklyn, New York, where she teaches government, healthcare and non-profit budgeting and financial management, research methods, and political economy. She obtained her $\mathrm{PhD}$ in Public Administration from Rutgers University. Her research interests centre on fiscal implications of economic cycles on sub-national governments and non-profit organisations, the municipal bond market, and the issue of gender in public administration. She has contributed to the Municipal Finance Journal, Administrative Theory \& Praxis, and Gender in Management: An International Journal. 
Maria J. D'Agostino is an Assistant Professor of Public Administration at John Jay College of Criminal Justice, CUNY, where she teaches public administration for the graduate and undergraduate programmes. She obtained his $\mathrm{PhD}$ in Public Administration from Rutgers University. Her research interests include public service, citizen involvement, and women and public administration. Her most recent publications include 'The career progression of women in state government agencies' published in Gender in Management: An International Journal and 'Securing an effective voice for citizens in intergovernmental administrative decision making' published in International Journal of Public Administration Review.

This paper is a revised and expanded version of a paper entitled 'The impact of volunteers on non-profits during times of fiscal stress' presented at the Northeast Business and Economic Association 2010 Conference, Morristown, New Jersey, 30 September to 2 October 2010.

\section{Introduction}

As part of the US Federal Government's response to the nation's economic crisis the non-profit sector and communities throughout the country have been called upon to contribute their service through volunteering. For example, The American Recovery and Reinvestment Act (ARRA) provided the Corporation for National and Community Service (CNCS), one of the nation's largest grant-providing federal agencies that supports volunteering, with over $\$ 200$ million to further expand the AmeriCorps State, National, and VISTA programmes. Also under the ARRA, \$50 million were provided to the strengthening communities fund (SCF), an initiative with the purpose of build[ing] the capacity of non-profit organisations ... to increase[e] [their] involvement in the economic recovery effort (US Department of Health and Human Services, 2010) ${ }^{1}$. Another example, the Edward M. Kennedy Serve America Act was signed into law in March 2009 with the intention of tripling the number of volunteers in the USA from 75,000 to 250,000 .

Although it may be that non-profit organisations are able to contribute to service delivery due to their regular use of volunteers (Ross and Brudney, 1998), it has also been shown that services provided by these organisations are not free (Brudney and Duncombe, 1992; Lipsky and Smith, 1989-1990); nor are non-profit managers always equipped to make the most of their volunteers (Urban Institute, 2004). Although a host of literature including Salamon and Sokolowski (2001), Ross and Brudney (1998) and Grantmaker (2003) examines the costs and benefits of volunteers in non-profit organisations, how managers cope with volunteers in light of the current recession is a timely and under-researched focus of study.

The purpose of this paper is to examine the challenges and benefits of volunteer involvement in non-profits during times of fiscal stress. The question posed is how do volunteers impact non-profits during times of fiscal stress? For instance, it may be that even though the value and expectations of volunteers are increasing in importance (Brudney and Meijs, 2009), the time available to serve is decreasing as the type of volunteer turns more to reflect societal and economic changes (Merrill, 2006). On the one hand the result is the concentration of a new prototype of episodic volunteer that has been shown to be a factor in non-profit organisations (Macduff, 1995; Brudney, 2005). On the 
other hand, as more citizens are either out of work or underemployed due to the state of the economy, an increasing number of professionals are volunteering their time, which has been reported as contributing to the organisation (Handy et al., 2008). As the federal government increasingly turns to non-profits, this study adds to the extant literature by discovering how volunteers impact non-profits during the current economic downturn.

Using Hager and Brudney's (2004) challenges and benefits framework, we develop and conduct semi-structured telephone interviews to a purposive sample of 20 administrators of New York City non-profits organisations. Then following Lozano and Valles (2007) a SWOT model is developed and evaluated to identify and categorise interviewees' responses based on benefits (strengths and opportunities) and challenges (weaknesses and threats). As non-profit organisations navigate their way through decreasing funding sources, increasing expenditures and a greater demand for services, understanding the impact of volunteers on non-profits is the first step in making the most of those who are looking to serve.

\section{Literature review}

\subsection{Volunteers and non-profits}

Since the end of World War II, partly as a response to the excessive growth of the welfare state, the US Federal Government has increased its reliance on non-governmental personnel to deliver publicly financed services (Brudney, 1990; Salamon et al., 2009). Also, there has been a growing consensus that the non-profit sector is a more efficient and effective provider of services (Osborne and Gaebler, 1992; Kotler and Lee, 2007). Particularly, the use of volunteers by non-profit organisations provides the potential for governments at all levels to lower their share of operation and service provision costs (Luksetich, 2008). Brudney (1993) for example, points out several advantages of volunteer involvement in the delivery of public services including

1 enhancement of government productivity

2 cost savings capabilities

3 improved quality of services and benefits in the community.

As a result governments in general, and the federal government in particular, often tap into volunteers through the use of non-profit organisations to ameliorate problems of eroding fiscal capacity, rising popular demands and expectations, and flagging citizen participation (Ross and Brudney, 1998).

It has also been observed (Grantmaker, 2003) that non-profits involve volunteers in diverse roles including web masters, designers and writers for newsletters, packing and distributing food to the hungry and feeding and caring for animals at the public zoos. In addition, volunteers also serve in many of the organisations' primary functions including board of directors, strategic partnerships, fundraising and development, organisational development and training, marketing and communications, financial management and accounting, technology and information systems, legal counsel, administrative support and programme and service delivery (Eisner et al., 2009). Given the scope of these responsibilities, many community organisations would cease to operate if not for the contributions of volunteers (Alexander, 2000). 
Moreover, a host of research including Salamon and Sokolowski (2001) and Cohen and McCambridge (2009) report not only the importance of volunteers, but also the growth in demands and expectations placed upon volunteers both domestically and worldwide. According to Independent Sector (n.d.), a coalition of charities, corporations and foundations, the estimated dollar value of volunteer time in 2009 was $\$ 20.85$, up from $\$ 20.25$ in $2008, \$ 19.51$ in 2007 and $\$ 18.77$ in 2006 . As a result, volunteers have become an essential component to the core mission of organisations.

Importantly, Merrill (2006) and Brudney and Meijs (2009) add that although the value and expectation of volunteers are increasing in importance, the time volunteers have available to serve has actually been decreasing as the 'type' of volunteer has begun to reflect of societal changes. For example, this 'type' of volunteer, commonly known as episodic volunteers:

1 accounts for more than half of all the volunteers in the USA

2 is more likely to be employed or to be in between jobs

3 has a limited time available to serve

4 has a greater need for immediate gratification [Kirsch et al. (2000) as ctd. in Brudney (2009)].

Moreover, as noted by Grantmaker (2003) episodic volunteers seek shorter assignments and are less likely to commit over a long period of time on a consistent basis. Bosman (2009) further indicates that the increase in episodic volunteers is especially prevalent during times of fiscal stress as individuals seek to make inroads and make use of their time. As a result, non-profits are spending resources, including time and money on orienting and training episodic volunteers, who end up leaving the organisation anyway. Arguably, from the point of view of a non-profit manager although there is an increasing need for volunteers, volunteer programmes may become cost prohibitive if a mounting number of episodic volunteers are employed (Femida and Srinivasan, 2005).

The problem that arises, however, as reported by the CNCS (2007), because non-profit volunteers are poorly managed, more than one-third of those who volunteer one year do not donate their time the next year at any non-profit organisation. In fact, in 2006 , of the 61.2 million people who volunteered their time, the CNCS (2007) further suggests that approximately 21.7 million people did not volunteer their time the following year resulting in an estimated $\$ 38$ billion lost in labour.

\section{Impact of recession on non-profit organisations}

As a result of the current recession, non-profits have increased their use of volunteers in terms of both number and amount of volunteer hours. Additionally, it is anticipated that non-profit reliance on volunteers will increase even further in 2010 and beyond (Salamon and Spence, 2009). However, regardless of the increase in volunteers during this time of fiscal stress, it may appear that non-profits are buffered from the impact of economic downturns due to governments' policies and partnerships that encourage volunteerism. However, the current economic crisis has had a critical impact on the non-profit sector as face a decline in revenues, not unlike their state and local government counterparts. In a 2009 survey of non-profit leaders conducted by the Alliance for Non-profit Excellence, 
non-profit leaders identified diverse strategies to deal with the economic downturn including intensifying fund raising opportunities and cutting what appears to be less essential items such as training and other forms of capacity building, including paid staff (Salamon and Spence, 2009). However, given the recent call to serve and focus on non-profits to take on more volunteers to serve, the decrease of capacity building may seem counter-intuitive.

According to a recent national survey of non-profits and AmeriCorps sponsored organisations, $80 \%$ of respondents have experienced some level of fiscal stress when the recent downturn intensified between September 2008 through March 2009 and 40\% identified the stress as 'severe' or 'very severe' (Salamon and Spence, 2009). Although about a quarter of non-profits responded by eliminating staff positions and postponing hiring for new positions, at the same time, three-fourths of the organisations reported they either maintained or increased the number of people served. Part of the reason this was possible was the increase in the use of volunteers. In fact, one of three organisations reported an increase in the reliance of volunteers during the months of September 2008 and March 2009; 48\% expected their reliance on volunteers to increase while 5\% expected it to decrease. Nonetheless, although about $39 \%$ of organisations reported an increase in the number of volunteers and volunteer hours, only $15 \%$ reported an increase in their ability to manage volunteers and $10 \%$ reported a decline in this ability. In addition, organisations that reported an inability to retain and recruit staff were more likely to report a decline in their ability to manage volunteers. Those organisations that reported an increased reliance on volunteers, and an increase in their ability to recruit and retain staff, were also more likely to report being 'somewhat' or 'very' successful financially as of March 2009 compared to those organisations that increased reliance on volunteers but suffered declines in their ability to attract and retain staff.

Overall, the financial conditions of late 2008 and 2009 have put increased fiscal stress on the ability of non-profits to cope effectively with increased volunteers (Cerrini et al., 2009; Salamon and Spence, 2009; Cohen and McAmbridge, 2009). The 2009 Long Island Non-for-profit Survey suggests that $77 \%$ of 124 respondents report that although funding has decreased as a result of the current recession the need for services has increased (Cerrini et al., 2009). Further, results of the John Hopkins Non-profit Listening Post Project testify that between September 2008 and March 2009, more than a third $(37 \%)$ of non-profit organisations report increasing the number of volunteers they use, and almost half (48\%) foresee increasing their usage of volunteers in the coming year.

\section{Method}

This research relies on qualitative data to assess the challenges and benefits of volunteers to non-profits during times of fiscal stress. In 2004, Hager and Brudney introduced a net benefits measure of organisational capacity and performance in volunteer organisations. Using Hager and Brudney's (2004) challenges and benefits framework of organisational capacity and performance in volunteer organisations, we developed semi-structured telephone interviews to understand the impact of volunteers on non-profits during times of fiscal stress. Participants were interviewed to determine the challenges (weaknesses and threats) and benefits (strengths and opportunities) of: 
1 volunteer management

2 extent of volunteer involvement

3 type of volunteer involvement.

\subsection{Definition of variables}

Borrowing from Hager and Brudney (2004) classification, the first category, volunteer management, is defined as the extent of adoption of management practices and the presence of a volunteer coordinator. The second category, extent of volunteer involvement, is defined as the scope of volunteer use and the number of different ways volunteers contributes to an organisation. The third category, type of volunteer involvement refers to the variety of ways an organisation can deploy a volunteer, including episodic, young and experienced volunteers. Next, following Lozano and Valles (2007) a SWOT model is developed and evaluated to identify and categorise responses based on benefits (strengths and opportunities) and challenges (weaknesses and threats). SWOT analysis was first developed by the business community to facilitate strategic planning. Particularly, SWOT analysis provides

1 a simple way of characterising the environment

2 an organised approach to brainstorming that helps to reveal insights that otherwise would not be apparent

3 assistance in assessing the real status of a given situation

4 the opportunity for future in-depth study (Rajagopal, 2008).

Although SWOT has been minimally used in the area of public administration (Lozano and Valles, 2007) it is increasingly being used in public health to assist public health care planners to plan for future resource scarcity (Usher-Pines et al., 2007) and in private and public organisations (Bernroider, 2002; El-Khishin, 2003; Jackson et al., 2003; Chiu and Yong, 2004; Dyson, 2004; Doratli et al., 2004; Sorensen et al., 2004; Srivastava et al., 2005).

\subsection{Data collection}

The data collection, in the form of semi-structured telephone interviews, took place over a two-week period from April 26, 2010 to May 10, 2010 from a purposive sample of 20 non-profit organisations identified as 'strengthening communities' non-profits. These non-profits qualified for SCF funding, that is, their mission contributes to the economic recovery effort. The non-profits, listed on the NYC.gov service website, have posted volunteer opportunities in the New York City area as part of the strengthening communities initiative.

Interview informants included executive directors and directors of non-profit organisations. Interview questions were e-mailed to participants prior to the scheduled interview. Of the 33 organisations contacted 20 agreed to be interviewed. Each of the interviews lasted approximately 20 to 30 minutes to complete and was designed to gain an understanding of the effectiveness of non-profits during times of fiscal stress. Although the sample size is not large enough for statistical analysis, in-depth interviews 
are capable of detecting sufficient variation among respondents and the thick description that results in .theoretical saturation (Strauss, 1987). Theoretical saturation is achieved when very few new findings are generated by the addition of individuals to the sample. It is also widely accepted that the sample size for individual interviewing is often fewer than 50 (Ritchie et al., 2003). To ensure internal validity, each interview was analysed and coded separately by each of the two authors and then compared for inter-related validity.

\section{Findings}

The number of full-time employees in our sample ranges from solely volunteers and other unpaid staff to over 150 full-time paid workers. All organisations are New York City based, listed on the NYC.gov service website who have posted volunteer opportunities in the New York City area as part of the strengthening communities initiative. The SCF and other initiatives, including the call to serve, were put forth with the specific intention of increasing non-profit involvement in the economic recovery. Non-profits in our research had annual operating budgets for fiscal year 2009 ranging from less than $\$ 25,000$ to over $\$ 6$ million.

Most of the interview respondents $(n=19)$ confirmed that the recession had negatively impacted their organisations. Only one of our interviewees reported that they had not been hit by the recession given that the organisation had no paid staff. Several respondents told us of the need for staff retrenchment, for example:

"[d]ue to lower revenues we have had to cut back and lay off $2 \frac{1}{2}$ staff member."

"[i]n June 2009 we were forced to retrench."

Loss of donations appeared to be another concern to the interviewees and the basis for laying-off full-time staff. As one volunteer director reported:

"[w]e have received fewer donations from individuals and foundations and as a result, we have a staff that is $10 \%$ less."

Another interviewee indicated:

"[u]nfortunately, we lost $85 \%$ of our dedicated donors (including in-kind) which affected our hiring status."

One executive director commented:

"[i]n some cases people who would have been available to volunteer prior to the recession were forced to seek full time employment."

Several of our respondents suggested that the economic downturn had also forced revisions in staffing patterns, including the use of more volunteers and hiring freezes. All but two of the administrators we spoke with reported that their organisations had experienced an increase in volunteers. We were told by one manager:

"[a]lthough we did not have to scale back on services we had to revise our staffing pattern. We can no longer hire staff members to work on our projects. Instead we had to recruit numerous volunteers to work on our projects, events, etc." 
Similarly, another manager stated:

"[w]e had to lay off employees to save money and volunteers helped to alleviate the impact while at the same time not depriving departments of their needs."

Also worth noting, one of the executive directors pointed out:

"[w]e had to recruit numerous volunteers to work on our projects, events, etc., even though in the past through donations we had the resources to hire consultants, artists, and other key players."

As one manager expressed:

"[w]e have so many volunteers - capped out at 1,100 volunteers and not recruiting any longer."

On the other hand, of the two interviewees in our sample that did not report an increase in volunteers, one mentioned:

"[we] did not have an increase in volunteers because we did not have the staffing resources to go out and recruit."

Whereas the second interviewee informed us:

"[s]ince we don't have any paid positions, there are no opportunities for volunteer jobs to turn into paid work so we didn't see an increase."

These responses corroborate the work of Cerrini et al. (2009) that despite an increase in volunteerism, the economic environment has also compromised non-profits' ability to cope effectively with increased volunteers. The SWOT model that emerged, as illustrated in Table 1 revealed 31 factors distinguished first by category, and then by the strength, weakness, opportunity or threat posed to the non-profit. For each element in the SWOT framework, key quotes are used to demonstrate the interviewees' points of view regarding the challenges and benefits of volunteers on their organisations during times of fiscal stress.

\subsection{Volunteer management}

\subsubsection{Benefits}

Non-profit managers have indicated varied strengths and opportunities to managing an increased number of volunteers during the fiscal downturn. Not only were managers receiving an increasing number of resumes they specifically indicated an influx of great resumes in professions ranging from investment bankers, web designers and IT techs to accountants and attorneys who were willing to volunteer their services in exchange for promoting their companies. As a result of the availability of such highly skilled volunteers, a few non-profits indicated they had the opportunity to expand services, such as one non-profit that started 'A Professionals in the Workplace' programme, and one that informed us of the role of highly skilled workers in the growth of their organisation. 
Table 1 Findings

\begin{tabular}{|c|c|c|c|}
\hline & Volunteer management & $\begin{array}{l}\text { Extent of volunteer } \\
\text { involvement }\end{array}$ & $\begin{array}{c}\text { Type of volunteer } \\
\text { involvement }\end{array}$ \\
\hline \multirow[t]{3}{*}{ Strength } & $\begin{array}{l}\text { More skilled volunteers } \\
\text { available }\end{array}$ & $\begin{array}{l}\text { Volunteers involved in } \\
\text { different activities }\end{array}$ & Episodic volunteer \\
\hline & $\begin{array}{l}\text { More volunteers to } \\
\text { complete tasks }\end{array}$ & $\begin{array}{l}\text { Volunteers take on key } \\
\text { roles in organisations }\end{array}$ & Young volunteer \\
\hline & $\begin{array}{l}\text { Skilled volunteers need } \\
\text { minimal training }\end{array}$ & $\begin{array}{l}\text { Increased task } \\
\text { permeability }\end{array}$ & Experienced volunteer \\
\hline \multirow[t]{3}{*}{ Weakness } & $\begin{array}{l}\text { Skilled worker may leave } \\
\text { once he/she finds a job }\end{array}$ & $\begin{array}{l}\text { Not enough tasks } \\
\text { available for increased } \\
\text { and more skilled } \\
\text { volunteers to complete }\end{array}$ & $\begin{array}{l}\text { Short-term, one } \\
\text { time commitment }\end{array}$ \\
\hline & $\begin{array}{l}\text { May not be able to place } \\
\text { increased number of } \\
\text { volunteers unless there is a } \\
\text { volunteer coordinator }\end{array}$ & Underutilisation of skills & $\begin{array}{l}\text { Limited time for } \\
\text { immediate gratification }\end{array}$ \\
\hline & $\begin{array}{l}\text { May not be able to place } \\
\text { all specialised skilled } \\
\text { volunteers }\end{array}$ & $\begin{array}{l}\text { Underutilisation of } \\
\text { experience }\end{array}$ & $\begin{array}{l}\text { Greater need for } \\
\text { immediate gratification }\end{array}$ \\
\hline \multirow[t]{3}{*}{ Opportunities } & $\begin{array}{l}\text { Can save money by } \\
\text { accepting skilled and } \\
\text { experienced volunteers }\end{array}$ & $\begin{array}{l}\text { More tasks completed } \\
\text { efficiently }\end{array}$ & $\begin{array}{l}\text { Volunteers bring } \\
\text { experience and skills to } \\
\text { organisation }\end{array}$ \\
\hline & $\begin{array}{l}\text { Can expand services to } \\
\text { more people }\end{array}$ & $\begin{array}{l}\text { More tasks completed } \\
\text { effectively }\end{array}$ & $\begin{array}{l}\text { Opportunity to get } \\
\text { volunteers interested in } \\
\text { future commitment }\end{array}$ \\
\hline & $\begin{array}{l}\text { Training can be refocused } \\
\text { on new paid positions in } \\
\text { areas of potential } \\
\text { expansion or where skills } \\
\text { have been lacking }\end{array}$ & & \\
\hline \multirow[t]{3}{*}{ Threats } & $\begin{array}{l}\text { Skilled workers may be } \\
\text { harder to retain }\end{array}$ & $\begin{array}{l}\text { Volunteers may not return } \\
\text { if not involved fulfilling } \\
\text { tasks }\end{array}$ & $\begin{array}{l}\text { Intransient and may } \\
\text { leave once permanent } \\
\text { position is found }\end{array}$ \\
\hline & $\begin{array}{l}\text { Non-profits may have to } \\
\text { turn away volunteers }\end{array}$ & May displace paid worker & $\begin{array}{l}\text { Volunteers may be } \\
\text { ineffective if } \\
\text { supervision and } \\
\text { training are not } \\
\text { available }\end{array}$ \\
\hline & $\begin{array}{l}\text { If no training is offered, } \\
\text { possibilities for unskilled } \\
\text { volunteers are limited }\end{array}$ & $\begin{array}{l}\text { Resistance on current } \\
\text { employees to volunteer } \\
\text { programmes }\end{array}$ & \\
\hline
\end{tabular}

\subsubsection{Challenges}

On the other hand, a number of managers reported a much different experience regarding the opportunities in managing the increasing numbers of volunteers. Several non-profits expressed frustration at not being in a position to seize the opportunity of working with the highly skilled pool of volunteers and therefore unable to expand services to better address the needs of the community. 
One manager stated:

"[w]e need to constantly identify our needs and narrow in on what we could expand so if this were to happen again we could be better positioned to make use of the volunteers to our advantage."

The fact that the influx of volunteers brought many highly skilled volunteers to the pool of those willing to contribute their time also meant that they were harder to place. The challenge confronting these non-profit managers was more than matching skills to an organisational need. Many of the volunteers were unemployed and seeking a volunteer opportunity to provide them with new skills. Moreover, the transient nature of the current pool of volunteers (i.e., many were in between jobs) posed a threat to the organisations' long term sustainability. The non-profit managers we spoke with voiced concern that the non-profit mission to service to the community would be compromised.

As one non-profit relayed to us:

"[t]he skilled volunteers are unemployed so once they find a job they leave and the tasks that they were able to take on just are left undone and pile-up."

A number of managers also acknowledged the challenges of not being able to support even those volunteers that came to serve with altruistic intentions. To the point, due to the loss of staff, there were no resources to recruit, train and/or supervise. For example as one volunteer manager expressed:

“[v]olunteers that were looking for a true volunteer opportunity - and not just a transition or job opportunity - we were not able to take on ... nor were we able to provide new or more services to the community."

Furthermore, the loss of staff also presented itself as a lost opportunity, not only for the volunteers, but also for the non-profits that would have valued the opportunity to take advantage of the increased interest in volunteering. As one manager responded:

"[b]ut since a bigger, meatier project takes a lot of time to prepare, it wasn't possible with less staff."

\subsection{Extent of volunteer involvement}

\subsubsection{Benefits}

Interviewees acknowledged several benefits due to the scope of volunteer use and the number of different ways volunteers contributed to their organisation, including task permeability, taking on key roles and completing tasks more efficiently. Several non-profit managers communicated that volunteers who had contributed their time prior to the recession had become even more active after losing their full-time jobs. As expressed by one volunteer manager:

"[o]ne of our volunteers lost her job last year so she has been more active as a result."

Moreover, not only have current volunteers been contributing more hours, many individuals who have been laid off and looking for volunteer opportunities have been able to take on key roles that were left vacant due to hiring freezes, retrenchment, or both. For example, non-profit managers reported placing volunteers in human resource positions as well as in consultant capacity. Notably, not only have volunteers helped to 
sustain non-profits during the recession, other opportunities and strengths surfaced. These volunteers have also made possible the opportunity to

1 be responsive to specific community needs by completing tasks that otherwise would have remained unfinished or low on the priority list

2 transfer skills to accomplish the same tasks as those performed by paid staff.

One manager shared a story about a volunteer that offered her services to revamp their entire website for free in exchange for grant writing for them on a regular basis. Although their website was in need of updating, it was a low priority and a task that otherwise would have remained unfinished had it not been for the volunteer. In fact several non-profit managers communicated that the volunteers have been so highly skilled that they have been able to give them a project and let them run with it without supervision. We were also told that the willingness of volunteers to take on more tasks in order to develop new skills was a welcome opportunity.

Overall, non-profits have been very receptive and accommodating to increased volunteer interest which has provided the opportunity for several non-profits to tailor requests to volunteer to specific emerging community needs. For example, as relayed to us by one volunteer manager:

\begin{abstract}
"[w]e have been able to develop many informal volunteer opportunities that are available via the website...that is anyone coming in wanting to give their time we try to develop an opportunity that suits their interests and that would help the community...for example, there has been an increased community need in resume writing and we have been able to match this need to volunteer skills and interest."
\end{abstract}

\title{
5.2.2 Challenges
}

The extent of volunteer involvement brings with it the major concern that many of these volunteers are in-between jobs and almost dive into volunteering as a therapeutic activity to avoid depression. As expressed by one volunteer manager:

"[t]he opportunity to volunteer after losing one's job is almost a luxury, in some cases people who were available to volunteer were forced to seek full time employment due to other family members losing their job."

Another manager brought to our attention that:

"[y]ou have to work and plan around a lot of schedules. It's not always easy to plan events or get work done in a timely fashion when you have to rely solely on volunteers. We had volunteers cancel on us at the last minute or if they were going to help with a function arrive hours late because of their other commitments."

However, aside from these difficulties, when prompted to discuss any weaknesses, including task unavailability and underutilisation of skills and experience, unanimously, none of our interviewees reported any of these weaknesses. These responses might reflect that volunteers are interested in serving in whatever available capacity is available to them. Specific to the economic downturn, it is also possible that volunteers will continue in the non-profit organisation with the expectation that a paid position will eventually develop. Lastly, only half our respondents affirmed the existence of a formal volunteer programme. One manager mentioned that: 
"[t]heir organization maintained a formal volunteer program for board of directors only."

\title{
5.3 Type of volunteer involvement
}

\subsubsection{Benefits}

The increased number of volunteers during the current economic downturn has provided some non-profits with the advantage of a more sustainable pool of volunteers. As articulated by one volunteer manager:

\begin{abstract}
"[w]e now have a more consistent core group of volunteers. They had usually come in once or twice a week, and then all of a sudden were coming in every single day of the week. Since the majority of these individuals suddenly had more time because they lost their jobs, most were not young recent college graduates but rather more experienced and looking to hone certain skills or make a career change. For instance, an individual was laid off from work and decided to pursue a career as a writer and thought that volunteering would help hone her skills."
\end{abstract}

However, given the current economy, a downside of this type of volunteer is that many pursue volunteer opportunities in non-profit organisations as if they were unemployment agencies. As a result, those non-profits that operated solely with volunteers, and not paid staff, have been less attractive to volunteers since they did not provide opportunities for volunteers to get hired. Consequently, several non-profits expressed frustration and poor utilisation of their limited resources. This concern is best articulated by some of the comments that emerged in our interviews:

\begin{abstract}
"[w]e were overwhelmed with people that wanted jobs ... it was almost a turnoff...we were looking for [volunteers], and spent a lot of time, selecting those that could give us a long term commitment and were interested in being here."
\end{abstract}

At the same time, other managers were concerned that the short-term availability of most volunteers did not suit their organisational mission. As best expressed by one manager:

\footnotetext{
"[g]iven the work we do with children we need consistency, a volunteer commitment for the long-term - at least one year; short term is not as good and that is mostly what has been available."
}

However, other non-profits would have liked to have been better positioned to capitalise on the short-term volunteers, for instance:

"[i]f our readers program were developed, we could have benefited from the availability of short-term volunteers."

Several other non-profits reflected on how they could use this opportunity to be more responsive to both volunteer interests and better meet community needs. For instance some non-profits utilised their VISTA volunteers to start new programmes.

"[o]ne of the NYC Vista volunteers we were awarded has been working on developing a pilot program that would develop opportunities for short-term volunteers and fill an organizational need."

"[w]e were awarded three VISTA volunteers that have been working to develop a new program, the Occasional Volunteer Adult Program ... this is an 
area where we can use and take advantage of the available occasional volunteers."

\subsubsection{Challenges}

Nonetheless, an increase in the number of short-term volunteers also presents issues of cost, training, and sustainability. For example, one respondent suggested:

"[w]e have seen an increase in volunteers over the past 5 years. In 2009 we worked with over 35 volunteers. This year we expect that number to double however we don't have the training available for all these volunteers."

An additional cost is the intransient nature of these volunteers that leads to concern of sustainability once a permanent position is found, as best expressed by some of the volunteer managers in our interviews

"[i]n our program we had forty volunteers this time last year that we trained and we invested our resources in them ... a year later we only have five volunteers and as the job market picks up I really don't think it will be the same...we still have a few people [volunteers] but not at this level."

\section{Discussion and conclusions}

The ARRA of 2009 provided federal departments and agencies with $\$ 787.2$ billion dollars to further economic recovery. The SCF and other initiatives were put forth with the specific intention of increasing non-profit involvement. This paper answered the research question, how do volunteers impact non-profits during times of fiscal stress? Our study built on previous non-profit literature, including Salamon and Sokolowski (2001) and Ross and Brudney (1993). Findings of semi-structured telephone interviews based on the SWOT framework support two conclusions.

On one hand, and supporting the work of Handy et al. (2008), findings of this study suggest that increased volunteerism benefits non-profits by contributing sustainability during the recession as a result of

1 the increased number of highly skilled volunteers

2 the ability of non-profits to expand services

3 task permeability.

On the other hand, our research bears out the caution put forth by Brudney and Duncombe (1992), and Lipsky and Smith (1989-1990) that it is not simply enough to have a call to service and expect non-profits to take on more volunteers to assist in service delivery. As evidenced by our interviewees and crucial to our findings, challenges include:

1 difficulty to recruit and train workers

2 volunteers' short term commitment

3 decrease in youth involvement.

Thus, not all non-profits have been able to make use of the available type of volunteers to assist them. 
Our findings also support Salamon and Spence's (2009) study that the financial conditions of late 2008 and 2009 have undisputedly put increased fiscal stress on the ability of non-profits to effectively serve the community. All but two of our respondents confirmed that the government's agenda, through the ARRA and other programmes, provided opportunities for non-profits to draw on an influx of a highly skilled pool of volunteers. Significantly, however, it appears that without the necessary staff and resources to recruit and take advantage of these opportunities, many non-profits are more likely to remain underfunded, understaffed and unequipped to address the needs of their communities. Going forward, non-profits will need to refocus their capacity to use highly skilled (e.g., pro bono) and one-time volunteers to reflect societal and economic changes in order to meet their missions. Importantly, we caution the implications of the decrease in youth involvement on civic engagement and youth development and suggest further study in this area.

In sum, various attempts by the government have enabled non-profits to continue, if not increase, services to communities during times of fiscal stress. Key to their continuance has been the use of volunteers; volunteers have provided the capacity for non-profits to develop specific programmes in order to address growing community needs during the current recession as well as sustain their core services. Nonetheless, it should not be overlooked or understated that the organisational changes taken to navigate through this torrid time may have long-term effects for government, non-profits, volunteers and the community.

Can programmes developed during this time be sustained once the majority of volunteers have returned to work? Have non-profits lost an opportunity to involve younger volunteers? Have non-profits had to re-focus their mission in order to survive? If so what does this mean for the community? What about the non-profits that have not been able to take advantage of short-term volunteers but still deliver critical services to the community? These are not only questions for future research but issues that need to be considered by non-profits and government if their partnership is to be an effective one in times of fiscal stress and during economic largess.

\section{References}

Alexander, J. (2000) 'Adaptive strategies of nonprofit human service organizations in an era of devolution and new public management', Nonprofit Management and Leadership, Vol. 10, No. 3, pp.287-303.

Bernroider, E. (2002) 'Factors in SWOT analysis applied to micro, small to medium and large software enterprises: an Austrian study', European Management Journal, Vol. 20, No. 5, pp.562-573.

Bosman, J. (2009) 'From ranks of jobless, a flood of volunteers', New York Times, 15 March, available at http://www.nytimes.com/2009/03/16/nyregion/16volunteers.html?pagewanted=1\&_r=1.

Brudney, J. (1990) Fostering Volunteer Programs in the Public Sector, Jossey-Bass, San Francisco.

Brudney, J. (1993) 'Volunteer involvement in the delivery of public services: advantages and disadvantages', Public Productivity and Management Review, Vol. 16, No. 3, pp.283-297.

Brudney, J. (2005) 'Designing and managing volunteer programs', in Herman, R.D. et al. (Eds.): The Jersey-Bass Handbook of Nonprofit Leadership and Management, 2nd ed., Wiley, New York. 
Brudney, J. and Meijs, L. (2009) 'It ain't natural: toward a new (natural) resource conceptualization for volunteer management', Nonprofit and Voluntary Sector Quarterly, Vol. 38, pp.564-581.

Brudney, J.L. and Duncombe, W.D. (1992) 'An economic evaluation of paid, volunteer, and mixed staffing options for public services', Public Administration Review, Vol. 52, No. 5, p.474.

Cerrini, K. et al. (2009) Long Island Not-for-profit Survey 2009, available at

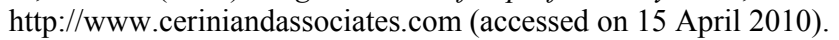

Chiu, A.S.F. and Yong, G. (2004) 'On the industrial ecology potential in Asian developing countries', Journal of Cleaner Production, Vol. 12, pp.1037-1045.

Cohen, R. and McCambridge, R. (2009) 'The state we're in: how bad is it out there?', The Nonprofit Quarterly, available at

http://www.nonprofitquarterly.org/index.php?option=com_content\&view=article\&id=1669\&It emid=162 (accessed on 28 March 2010).

Corporation for National and Community Service (CNCS) (2007) 'New federal report shows volunteering strong in America, but 1 in 3 volunteers out in 2006', available at $\mathrm{http}: / / w w w . n a t i o n a l s e r v i c e . o r g / a b o u t / n e w s r o o m / r e l e a s e s \_d e t a i l . a s p ? t b l$ prid-682 (accessed on 1 November 2007).

Doratli, N., Hoskara, S.O. and Fasli, M. (2004) 'An analytical methodology for revitalization strategies in historic urban quarters: a case study of the Walled City of Nicosia, North Cyprus', Cities, Vol. 21, No. 4, pp.329-348.

Dyson, R. (2004) 'Strategic development and SWOT analysis at the University of Warwick', European Journal of Operational Research, Vol. 152, pp.631-640.

Eisner, D., Grimm, R.T., Jr., Maynard, S. and Washburn, S. (2009) 'The new volunteer workforce', Stanford Social Innovation Review, Winter, pp.32-37, available at http://www.ssireview.org/articles/entry/the_new_volunteer_workforce/et al.

El-Khishin, K. (2003) 'Bidding for global city status: a prescription for sustaining Cairo's financial health', Cities, Vol. 20, No. 2, pp.129-134.

Femida, H. and Srinivasan, N. (2005) 'The demand for volunteer labor: a study of hospital volunteers', Nonprofit and Voluntary Sector Quarterly, Vol. 34, No, 4, pp.491-509.

Grantmaker (2003) 'The cost of a volunteer: what it takes to provide a quality volunteer experience', The Grantmaker Forum on Community \& National Service, available at http://www.pacefunders.org.

Hager, M.A. and Brudney, J.L. (2004) Volunteer Management: Practices and Retention of Volunteers, The Urban Institute, Washington, DC.

Handy, F., Mook, L. and Quarter, J. (2008) 'The interchangeability of paid staff and volunteers in nonprofit organizations', Nonprofit and Voluntary Sector Quarterly, Vol. 37, pp.76-92.

Independent Sector (n.d.) available at http://www.independentsector.org/volunteer_time.

Jackson, S., Joshi, A. and Erhardt, N. (2003) 'Recent research on team and organizational diversity: SWOT analysis and implications', Journal of Management, Vol. 29, No. 6, pp.801-830.

Kirsch, A.D., Hume, K.M. and Jalandoni, N.T. (2000) Giving and Volunteering in the United States: Findings from a National Survey (1999 ed.)', Washington, DC.

Kotler, P. and Lee, N.R. (2007) 'Marketing in the public sector: the final frontier', Public Manager, Vol. 36, No. 1, pp.12-17.

Lipsky, M. and Smith, S.R. (1989-1990) 'Nonprofit organizations, government, and the welfare state', Political Science Quarterly, Vol. 104, No. 4, pp.625-648.

Lozano, H. and Valles, J. (2007) 'An analysis of the implementation of an environmental management system in a local public administration', Journal of Environmental Management, Vol. 82, No. 4, pp.495-511.

Luksetich, W. (2008) 'Government funding and nonprofit organization', Nonprofit and Voluntary Sector Quarterly, Vol. 37, pp.3434-3442.

Macduff, N. (1995) 'Episodic volunteering', in Connors, T.D. (Ed.): The Volunteer Management Handbook, Wiley, New York. 
Merrill, M.V. (2006) 'Global trends and challenges for volunteering', International Journal of Volunteer Administration, Vol. 24, No. 1, pp.9-14.

Osborne, D. and Gaebler, T. (1992) Reinventing Government: How the Entrepreneurial Spirit Is Transforming the Public Sector, Addison-Wesley, Reading, MA.

Rajagopal, V. (2008) 'SWOT analysis on Indian scientific research', Current Science, Vol. 94, No. 7, pp.846-847.

Ritchie, J., Lewis, J. and Elam, G. (2003) 'Designing and selecting samples', in Ritchie, J. and Lewis, J. (Eds.): Qualitative Research: A Guide for Social Science Students and Researchers, Sage Publications, London.

Ross, M. and Brudney, J. (1998) 'Volunteer administration: useful techniques for the public sector', Journal of Volunteer Administration, Vol. 6, pp.27-33.

Salamon, L., Geller, S. and Spence, K. (2009) Impact of the 2007-09 Economic Recession on Nonprofit Organizations, available at http://www.ccss.jhu.edu/pdfs/LP_Communiques/LP_Communique_14.pdf.

Salamon, L.M. and Sokolowski, W. (2001) 'Volunteering in cross-national perspective: evidence from 24 countries', Working Paper of the Johns Hopkins Comparative Nonprofits Sector Project No. 40, The Johns Hopkins Center for Civil Society Studies, Baltimore.

Salamon, L.M. and Spence, K. (2009) Volunteers and the Economic Downturn, available at http://www.volunteeringinamerica.gov.

Sorensen, L., Vidal, V.V. and Engstron, E. (2004) 'Using soft OR in a small company - the case of Kirby', European Journal of Operational Research, Vol. 152, pp.555-570.

Srivastava, P.K., Kulshreshtha, K., Mohanty, C.S., Pushpangadan, P. and Singh, A. (2005) 'Stakeolder-based SWOT analysis for successful municipal solid waste management in Lucknow, India', Waste Management, Vol. 25, No. 5, pp.531-537.

Strauss, A. (1987) Qualitative Research for Social Scientists, Cambridge University, Cambridge.

Urban Institute (2004) Volunteer Management Capacity in American's Charities and Congregations, available at http://www.urbaninstitute.org.

US Department of Health and Human Services (2010) available at http://www.acf.hhs.gov/index.html (accessed on 29 May 2010).

Usher-Pines, L., Barnett, D., Sapsina, J., Bishaic, D., Ran, D. and Balicer, R. (2007) 'A systematic analysis of influenza vaccine shortage policies', Journal of the Royal Institute of Public Health, Vol. 122, pp.183-191.

\section{Notes}

1 The SCF is authorised under Section 1110 of the Social Security Act governing social services research and demonstration activities; Title VIII of the ARRA of 2009, Public Law (P.L.) 111-5. The SCF is made up of a second programme aimed at state, local, and tribal government capacity building programmes, which is beyond the scope of this study. 